\title{
ATTITUDES TOWARDS ANTIPSYCHOTIC DRUGS AND THEIR SIDE EFFECTS: A COMPARISON BETWEEN STUDENTS OF MEDICINE IN SPAIN AND SERBIA
}

Teresa Alvarado Casas ${ }^{1}$, Marko M. Folic ${ }^{2,3}$, Nevena D. Folic ${ }^{4}$ and Slobodan M. Jankovic ${ }^{2,3}$

${ }^{1}$ Medical Faculty, University of Alcalá de Henares, Madrid, Spain

${ }^{2}$ Medical Faculty, University of Kragujevac, Kragujevac, Serbia

${ }^{3}$ Pharmacology Department, Clinical Center Kragujevac, Kragujevac, Serbia

${ }^{4}$ Pediatric Clinic, Clinical Center Kragujevac, Kragujevac, Serbia

\section{POREDENJE STAVOVA STUDENATA MEDICINE ŠPANIJE I SRBIJE PREMA ANTIPSIHOTICIMA I NJIHOVIM NEŽELJENIM EFEKTIMA \\ ${ }^{1}$ Medicinski fakultet, Univerzitet Alcalá de Henares, Madrid, Španija \\ ${ }^{2}$ Medicinski fakultet, Univerzitet u Kragujevcu, Kragujevac, Srbija \\ ${ }^{3}$ Služba za kliničku farmakologiju, Klinički centar Kragujevac, Kragujevac, Srbija \\ ${ }^{4}$ Pedijatrijska klinika, Klinički centar Kragujevac, Kragujevac, Srbija}

Received / Primljen: 18. 09. 2011.

Accepted / Prihvaćen: 01. 12. 2011.

\section{ABSTRACT}

Background. The appropriate use of antipsychotics by general practitioners is correlated with a positive attitude towards this group of drugs during their undergraduate studies.

Objective. The aim of our study was to investigate and compare the attitudes of medical students in Spain and Serbia wards about the effectiveness and adverse effects of antipsychotic medications.

Methods. In a cross-sectional study, 60 final-year medical students from Spain and Serbia were exposed to a case of a patient treated with antipsychotics who was experiencing side effects. A Likert-type questionnaire was then given to the students, capturing their attitudes towards antipsychotics.

Results. Compared to the Spanish peers, the students from Serbia were more eager to use antipsychotics as a means of protecting the patients' families than forto help the patients themselves. The majority of the Serbian students thought that psychotic patients were supposed to tolerate the side effects of their medications, while the Spanish students were ready to change their treatment. The Serbian students were older than their Spanish peers, mostly males and Orthodox.

Conclusions. Additional educational efforts are needed to improve the attitudes of older and more religious students, but these efforts will pay off in the future with more appropriate drug treatment of schizophrenic patients and improved patient adherence to the treatment.

Key Words: Antipsychotics; medical students; attitude; education.

\section{SAŽETAK}

Uvod. Adekvatno propisivanje antipsihotika od strane lekara opšte prakse u korelaciji je sa njihovim pozitivnim stavom o ovoj grupi lekova stečenim u toku osnovnih akademskih studija medicine.

Cilj. Ispitati $i$ uporediti stavove studenata medicine iz Španije $i$ Srbije o terapijskoj efikasnosti $i$ neželjenim efektima antipsihotika.

Metode. Uovojstudijipreseka, 60studenata završne godine medicine iz Španije i Srbije primarno je upoznato sa slučajem pacijenta kome je indikovana terapija karakterističnim antipsihotikom uz razvoj određenih pratecih nuspojava. Učesnici u istraživanju su potom, u cilju procene njihovog stava prema antipsihoticima, popunjavali upitnik Lickert tipa.

Rezultati. U poređenju sa španskim "vršnjacima”, studenti iz Srbije bili su više naklonjeni antipsihoticima kao sredstvu zaštite porodice pacijenta nego kao vidu medikamentozne pomoći samim pacijentima. Većina studenata iz Srbije je smatrala da bi psihotični pacijenti trebalo da tolerišu eventualna manifestna neželjena dejstva lekova iz pomenute grupe, dok španski studenti, u takvim slučajevima bi preferirali promenu terapijskog tretmana. Srpski studenti završne godine bili su stariji od španskih kolega, uglavnom muškog pola i Pravoslavne veroispovesti.

Zaključak. Potrebni su dodatni obrazovni napori kako bi se unapredili stavovi starijih $i$ religioznijih studenata $i$ koji bi se u budućnosti isplatili adakvatnim terapijskim izborom kod psihotičnih pacijenata i njihovom povećanom adherencom na indikovani medikamentozni tretman.

Ključne reči: Antipsihotici; studenati medicine, stav, obrazovanje.

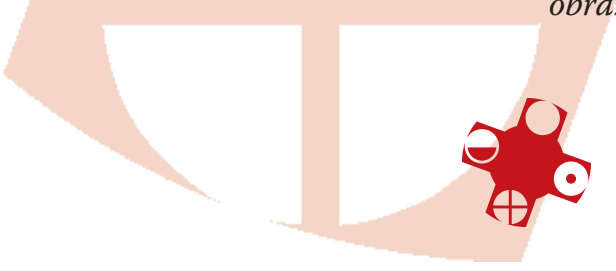




\section{INTRODUCTION}

Attitudes towards antipsychotic medications are very important for achieving success in the treatment of patients with schizophrenia (1). Positive attitudes of prescribing physicians and good doctor-patient communication and relationships can improve patient compliance with prescribed medications and tolerance of their side effects $(2,3)$. Because the attitudes of general practitioners towards diseases and treatments are mostly formed during their undergraduate studies (4), creating positive attitudes among medical students is an important challenge for medical educators. Potentially successful programs should consider the numerous factors that may influence attitude, including religion and national and local culture (5).

There are several studies in different countries that have reported mostly negative attitudes of medical students towards schizophrenia $(6,7,8)$. One recent cross-cultural study demonstrated a significant influence of religion on the attitudes of medical students towards schizophrenia (9). However, we are not aware of any published studies dealing with the attitudes of medical students towards the effectiveness and adverse effects of antipsychotic medications, although this is an important aspect of a schizophrenic patient's life. The attitudes towards antipsychotic medications may influence thethe students' overall attitudes towards these patients. The aim of our study was to investigate and compare the attitudes of medical students in Spain and Serbia wards about the effectiveness and adverse effects of antipsychotic medications.

\section{MATERIALS AND METHODS}

\section{Study population}

The study population consisted of final-year students of medicine from the Medical Faculties in Madrid (Spain) and Kragujevac (Serbia) who were studying during the winter semester of the 2010-2011 school year. The students in both Medical Faculties had completed their lessons on psychiatry. Out of 300 students from Barcelona and 195 students from Kragujevac, two samples of 30 students each were chosen according to the convenience of the investigators.

\section{Study protocol}

After being approached by the investigators and presented with the purpose of the study, the students were given the following case of a patient receiving antipsy- chotics to read: "Male patient B.N. of Caucasian origin, 35 years old, has been suffering from schizophrenia for more than 5 years. For the last three years, the signs and symptoms of his disease have been well controlled by one antipsychotic drug, fluphenazine $5 \mathrm{mg}$ daily, orally. However, the patient has several side effects from this medication. He is constantly tired, sweats heavily, and he has to consume large amounts of water with meals due to a dry mouth. His body mass index is now 27 , and it anis continuing to increase. He has become impotent and has lost any interest for the leisure and sport activities that were his main preoccupation before he started taking the medication. His hands shake during both rest and activity, and he frequently puckers and purses his lips involuntarily. He also has a feeling of unrest. In spite of all these side effects, the patient is consistently taking his medication every day". As soon as the students read the case, the same investigators gave them a questionnaire, already used by Helbling and associates ${ }^{1}$, which was composed of two parts. In the first part, there were 7 Likert-type questions that measured the attitudes of the students towards antipsychotic drugs. The second part listed the 10 adverse reactions experienced by the patient described in the case, giving the students an opportunity to express their opinions about how long the described patient should tolerate such reactions. The religious beliefs of the students were determined from their statements. The students' participation in the study was finished after completion of the questionnaire.

\section{Study design}

The study was set up as observational cross-sectional study, conducted on one occasion at two remote sites. Based on an expected difference of $36 \%$ in the attitudes of the students from Barcelona and Kragujevac, a probability of type I (alpha) error of 0.05 when using the Chi-squared test, and a power of $80 \%$, the minimal sample size was calculated by G"Power3 software $(10,11)$ to be 29 patients per group.

\section{Statistics}

For the continuous variables in each group, the mean and standard deviation were calculated. The differences between the means were tested by Student's T-test for small independent samples. The differences in frequencies of the dichotomous variables among the groups were tested for significance by the Chi-squared test (12). The probability of the null hypothesis was set to a value of 0.05 . All calculations were made by the statistical software SPSS version 18 .

\begin{tabular}{|l|l|l|l|}
\hline CHARACTERISTIC & MADRID & KRAGUJEVAC & DIFFERENCE \\
\hline Number of students & 30 & 30 & N/A \\
\hline Age $( \pm$ standard deviation) & $23.3 \pm 1.1$ & $25.7 \pm 1.1$ & T-test $=9.224, \mathrm{df}=56, \mathrm{p}=0.000$ \\
\hline Sex $(\mathrm{M} / \mathrm{F})$ & $7 / 23$ & $18 / 12$ & $\chi^{2}=8.400, \mathrm{df}=1, \mathrm{p}=0.004$ \\
\hline Religion $($ Catholic/Orthodox/atheist) & $16 / 0 / 14$ & $0 / 29 / 1$ & $\chi^{2}=52.231, \mathrm{df}=2, \mathrm{p}=0.000$ \\
\hline
\end{tabular}

Table 1. Characteristics of the study groups. 


\section{RESULTS}

The baseline characteristics of the study groups are shown in Table 1 . The study groups did not differ significantly in their attitudes towards the risk of dependency on antipsychotics $\left(\chi^{2}=3.527, \mathrm{df}=2, \mathrm{p}=0.171\right)$, benefit $/$ risk ratio $\left(\chi^{2}=3.419\right.$, $\mathrm{df}=2, \mathrm{p}=0.181)$, effectiveness $\left(\chi^{2}=1.967, \mathrm{df}=2, \mathrm{p}=0.374\right)$, safety $\left(\chi^{2}=5.426, \mathrm{df}=2, \mathrm{p}=0.066\right)$ or beneficial effect of antipsychotics on social functioning $\left(\chi^{2}=0.481, \mathrm{df}=2, \mathrm{p}=0.786\right)$. However, while 25 (83\%) of the students from Spain agreed that antipsychotics are the most effective way to treat mental illness, only $13(43 \%)$ of the students from Serbia shared the same attitude $\left(\chi^{2}=14.076, \mathrm{df}=2, \mathrm{p}=0.001\right)$. On the other hand, $21(70 \%)$ of the students from Serbia thought that mentally ill people are only tolerable to their families due to antipsychotics, while only $2(7 \%)$ of the students from Spain had the same opinion $\left(\chi^{2}=49.915, \mathrm{df}=2, \mathrm{p}=0.000\right)$.

The study groups did not differ significantly in their readiness to accept the following adverse reactions in patients taking antipsychotics: unpleasant dry mouth $\left(\chi^{2}=1.144, \mathrm{df}=2, \mathrm{p}=0.564\right)$, heavy sweating $\left(\chi^{2}=0.678, \mathrm{df}=2\right.$, $\mathrm{p}=0.996)$, constant tiredness $\left(\chi^{2}=1.036, \mathrm{df}=2, \mathrm{p}=0.596\right)$, continuous feeling of unrest $\left(\chi^{2}=0.530, \mathrm{df}=2, \mathrm{p}=0.767\right)$, significant weight gain $\left(\chi^{2}=3.764, \mathrm{df}=2, \mathrm{p}=0.152\right)$ and visible movement disorder $\left(\chi^{2}=3.546, \mathrm{df}=2, \mathrm{p}=0.170\right)$. However, the students in Spain were significantly less ready to tolerate frequent sexual dysfunction $\left(\chi^{2}=9.866, \mathrm{df}=2, \mathrm{p}=0.007\right)$, continuous anhedonia $\left(\chi^{2}=14.901, \mathrm{df}=2, \mathrm{p}=0.001\right)$, risk of drug dependency $\left(\chi^{2}=7.533, \mathrm{df}=2, \mathrm{p}=0.023\right)$ and marked tremor $\left(\chi^{2}=14.346, \mathrm{df}=2, \mathrm{p}=0.001\right)$ (Figure 1).

\section{DISCUSSION}

This comparison of the attitudes of medical students from Spain and Serbia towards antipsychotics has shown important differences. The students from Serbia mostly saw antipsychotics as a means of protecting the patients families rather than a means of helping the patients themselves. AlsoAdditionally, the majority of the Serbian students thought that psychotic patients were supposed to tolerate the side effects of their medications without complaint, while the Spanish students were ready to help to the virtual patient by changing something in his drug regimen. Behind these differences, there could be a hidden negative attitude towards psychotic patients among the majority of the Serbian students, making them believe that these patients should not be treated in the same way as patients suffering from physical illnesses.

The observed differences in attitudes could be associated with differences in age, sex orand religion. The Serbian students were mostly older, male and Orthodox. It has already been shown that cultural beliefs and religion have a stronger influence than experience in learning psychiatry on the attitudes of medical students and physicians towards psychotic patients $(13,14)$. Older age of health workers is also a significant predictor of discriminating

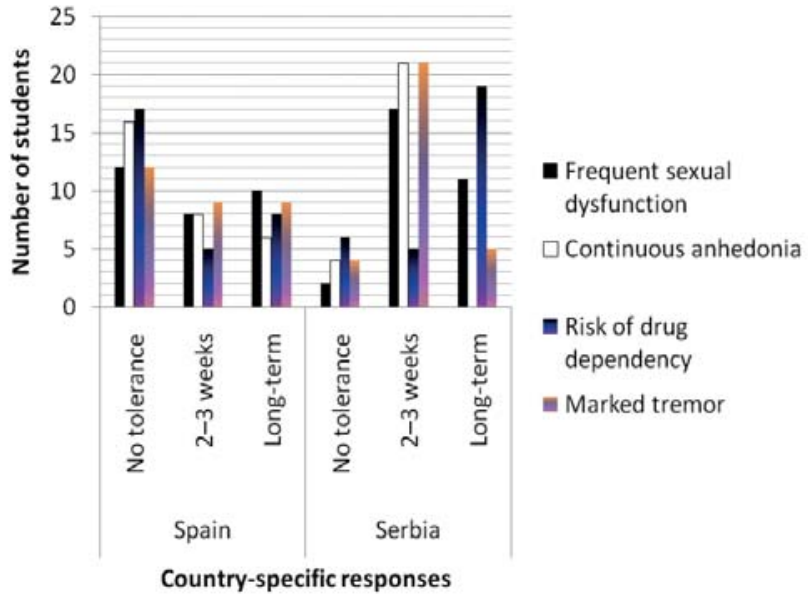

Figure 1. Differences between countries in attitudes towards the tolerability of antipsychotic medication adverse reactions.

attitudes towards psychotic patients (15), but male sex is not associated with a negative view of the disease itself or antipsychotic drugs (16).

To make attitudes towards psychotic patients and their medications more rational among medical students, educators should pay special attention to the cultural beliefs of the students. Additional educational efforts are needed to improve the attitudes of older and more religious students, but these efforts will pay off in the future with more appropriate drug treatment of schizophrenic patients and increased patient adherence to the treatment.

Our study was limited by an unrepresentative sample and failure to account for other factors that may affect students' attitudes related to the usage of antipsychotics. Additionally, the degree of religiosity was not investigated. For these reasons, the results of this research should be considered only preliminary; new studies, with much larger sample sizes and a significantly larger number of studied parameters, are needed to provide a definitive conclusion.

\section{REFERENCES}

1. Helbling J, Ajdacic-Gross V, Lauber C, Weyermann R, Burns $\mathrm{T}$, Rössler W. Attitudes to antipsychotic drugs and their side effects: a comparison between general practitioners and the general population. BMC Psychiatry 2006; 6: 42

2. Rettenbacher MA, Hofer A, Eder U, Hummer M, Kemmler G, Weiss EM, Fleischhacker WW. Compliance in schizophrenia: psychopathology, side effects, and patients' attitudes toward the illness and medication. J Clin Psychiatry 2004; 65: 1211-8.

3. Vauth R, Loschmann C, Rusch N, Corrigan PW. Understanding adherence to neuroleptic treatment in schizophrenia. Psychiatry Res 2004; 126: 43-9.

4. Berwick DM, Finkelstein JA. Preparing medical students for the continual improvement of health and health care: Abraham Flexner and the new "public interest”. Acad Med 2010; 85 (9 Suppl): S56-65. 
5. Galazios G, Dafopoulos K, Koutlaki N, Liberis V, Tsikouras P, Anastasiadis P. Attitudes towards contraceptive pill use in two different populations in Thrace, Greece. Eur J Contracept Reprod Health Care 2002; 7: 127-31.

6. Llerena A, Cठceres MC, Pecas-LLedy EM. Schizophrenia stigma among medical and nursing undergraduates. Eur Psychiatry 2002; 17: 298-9.

7. Fernando SM, Deane FP, McLeod HJ. Sri Lankan doctors' and medical undergraduates' attitudes towards mental illness. Soc Psychiatry Psychiatr Epidemiol 2010; 45: 733-9.

8. Dixon RP, Roberts LM, Lawrie S, Jones LA, Humphreys MS. Medical students' attitudes to psychiatric illness in primary care. Med Educ 2008; 42: 1080-7.

9. Furnham A, Raja N, Khan UA. A cross-cultural comparison of British and Pakistani medical students' understanding of schizophrenia. Psychiatry Res 2008; 159: 308-19.

10. Faul F, Erdfelder E, Buchner A, Lang AG. Statistical power analyses using $G$ *Power 3.1: Tests for correlation and regression analyses. Behavior Research Methods 2009; 41: 1149-1160.
11. Faul F, Erdfelder E, Lang AG, Buchner A. G*Power 3: A flexible statistical power analysis program for the social, behavioral, and biomedical sciences. Behavior Research Methods 2007; 39: 175-191.

12. Machin D, Campbell MJ, Walters SJ. Medical statistics: a textbook for the health sciences. 4th ed. John Wiley \& Sons, Chichester, U.K., 2007.

13. Muga F, Hagali M. What do final year medical students at the University of Papua New Guinea think of psychiatry? P N G Med J 2006; 49: 126-36.

14. Feinberg SS. Issues in the psychopharmacologic assessment and treatment of the orthodox Jewish patient. CNS Spectr 2005; 10: 954-65.

15. Steinert T, Hinbber W, Arenz D, Ruttgers HR, Biller N, Gebhardt RP. Ethical conflicts in involuntary treatment of schizophrenic patients; decision-making and in influential factors in three prototype cases. Nervenarzt 2001; 72: 700-8.

16. Bell JS, Aaltonen SE, Airaksinen MS at al. Determinants of mental health stigma among pharmacy students in Australia, Belgium, Estonia, Finland, India and Latvia. Int J Soc Psychiatry 2010; 56: 3-14.
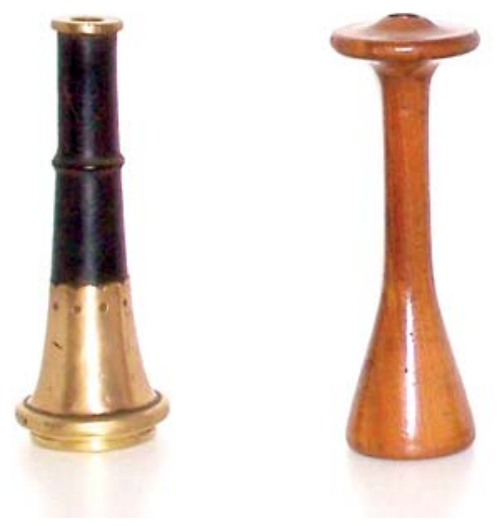

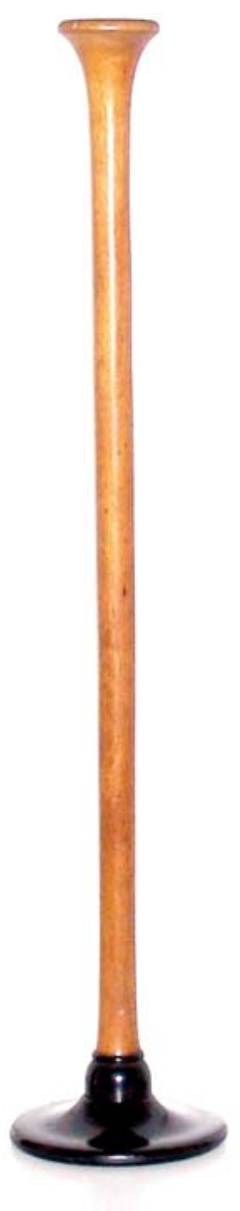

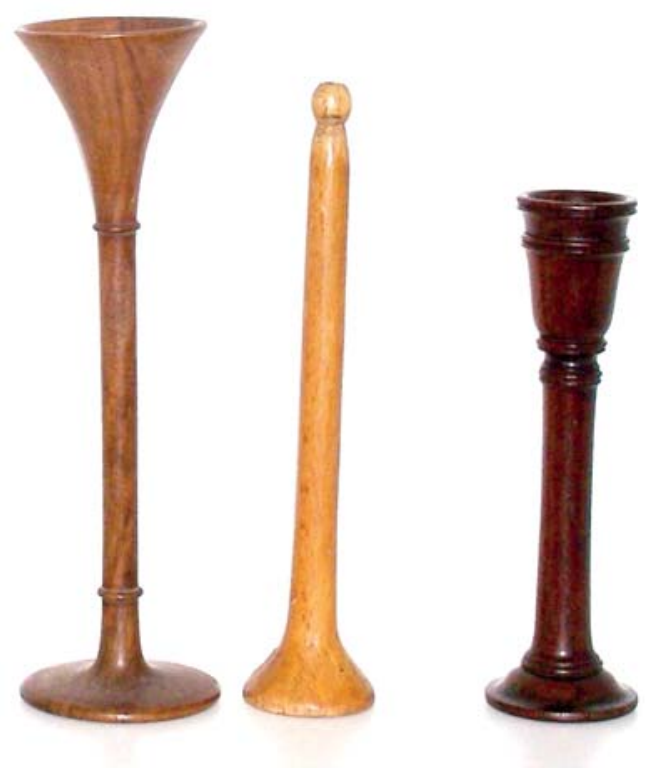

